\title{
Research Article: Adoption of sustainable cultivation practices followed by strawberry growers
}

Article Chronicle:

Received :

12.07.2017;

Accepted :

25.07.2017

Key Words :

Adoption,

Sustainable

cultivation,

Strawberry

cultivation
SUMMARY : Globally, strawberries are grown in huge quantities in Australia, the U.S.A. (California and Florida), Italy, Germany, Spain and France. Strawberry is important fruit crop of India and its commercial production is possible in temperate and subtropical climate. In India it is generally cultivated in the hills. Strawberry is also successfully cultivated in plains also in Maharashtra around Pune, Nashik and Sangali districts of Maharashtra. The present study on adoption of sustainable cultivation practices followed by strawberry growers was undertaken in Mahabaleshawar tehsil of Satara district region of western Maharashtra State with sample size of 110 respondents from 6 villages. Data were collected on personal, socio-economic, communicational and psychological profile of farmers and knowledge and adoption sustainable practices was certain by using exploratory design of social research. Data from the respondents were collected by personally interviewing with the help of present and wellstructured interview schedule. About 61.82 per cent of the respondents have medium level of adoption about sustainable cultivation practices followed in strawberry cultivation.

How to cite this article : Mujawar, R.H., Patil R.L., Gaikwad, S.S. and Bhange, S.B. (2017). Adoption of sustainable cultivation practices followed by strawberry growers. Agric. Update, 12(TECHSEAR-2) : 559-566; DOI: 10.15740/HAS/AU/12.TECHSEAR(2)2017/559-566.
Author for correspondence :

\section{R.H. MUJAWAR}

Department of Extension Education, Post Graduate Institute, Mahatma Phule Krishi Vidyapeeth, Rahuri, AHMEDNAGAR (M.S.) INDIA

Email: riteshlpatil92

@ gmail.com

See end of the article for authors' affiliations 